\title{
PEMETAAN PERILAKU PESEPEDA PRA DAN PASCA PANDEMI COVID-19 DI PROVINSI BALI MENGGUNAKAN DATA STRAVA METRO
}

\author{
Anggun Prima Gilang Rupaka ${ }^{1}$, Aris Budi Sulistyo ${ }^{1}$, Dewa Punia ${ }^{2}$ \\ ${ }^{1}$ Manajemen Transportasi Jalan, Politeknik Transportasi Darat Bali, Jalan Cempaka Putih Tabanan, Indonesia \\ 82111 \\ ${ }^{2}$ Sekolah Tinggi Transportasi Darat Bekasi, Jl. Raya Setu No.58, Mekarwangi, Kec. Setu, Bekasi, Jawa Barat, \\ Indonesia 17530 \\ *gilang@poltradabali.ac.id
}

\begin{abstract}
ABSTRAK
Pandemi Covid-19 yang melanda dunia membuat semua pemerintahan negara dan daerah membuat peraturan karantina bernama Pembatasan Sosial Berskala Besar (PSBB). Pelaksanaan PSBB pada bulan Maret hingga Mei 2020 mengakibatkan banyak dampak baik positif dan negatif. Dampak positif yang muncul akibat PSBB tersebut salah satunya booming-nya hobi bersepeda masyarakat di Indonesia. Booming tersebut akibat dari masyarakat yang tidak dapat bepergian dan berlibur ke luar kota atau ke luar negeri sehingga mencari cara untuk menyegarkan pikiran dengan cara bersepeda keliling kota. Penelitian ini menggunakan data dari Strava Metro dari tahun 2017 - November 2020. Strava Metro adalah bagian dari Stava, aplikasi media sosial bagi pada pehobi olahraga khususnya sepeda, lari, renang dan lain-lain. Strava menghimpun data penggunanya yang meliputi jarak tempuh, jumlah perjalanan, jumlah orang, dan asal pesepeda (lokal atau wisatawan) dengan tanpa menampilkan data pribadi penggunanya. Penelitian ini memetakan perilaku pesepeda sebelum dan sesudah PSBB dengan membandingkan data dari 2020, terutama pada bulan Maret - November 2020, dengan data dari tahun sebelumnya. Peningkatan jumlah orang dan perjalanan pesepeda belum diiringi dengan dukungan pemerintah daerah. Jalur sepeda di Pulau Bali hanya terdapat di Kota Denpasar sepanjang $25 \mathrm{~km}$.
\end{abstract}

Kata kunci: pandemi; perilaku pesepeda; strava

\section{BEHAVIOR MAPPING OF BALI PRE AND POST-PANDEMIC BIKES IN BALI PROVINCE USING METRO STRAVA DATA}

\begin{abstract}
The Covid-19 pandemic that has hit the world has made all state and regional governments make quarantine regulations called Large-Scale Social Restrictions (PSBB). The implementation of the PSBB from March to May 2020 had many positive and negative impacts. One of the positive impacts arising from the PSBB was the cycling boom in Indonesia. The boom is a result of people who cannot travel and have a vacation outside the city or abroad, so they are looking for ways to refresh their minds by cycling around the city. This research uses data from Strava Metro from 2017 - November 2020. Strava Metro is part of Stava, a social media application for sports enthusiasts, especially bicycles, running, swimming and others. Strava collects user data which includes distance traveled, number of trips, number of people, and origin of cyclists (local or tourist) anonymously. This study will map the behavior of cyclists before and after the PSBB by comparing data from 2020, especially in March November 2020, with data from the previous year. The increase in the number of people and cyclist trips has not been accompanied by the support of the local government. Bicycle paths on the island of Bali are only available in Denpasar City along $25 \mathrm{~km}$.
\end{abstract}

Keywords: pandemic, cyclist behavior, strava

\section{PENDAHULUAN}

Pandemi Covid-19 yang menerpa dunia pada bulan Januari tahun 2020 sampai sekarang banyak menimbulkan dampak baik dari segi sosial, ekonomi, geo politik, sains, perilaku manusia, dan lain-lain. Penyebaran virus Covid-19 yang sangat cepat pada 182 dari 202 negara di dunia sehingga semua negara menerapkan strategi social distancing untuk mencegah penyebaran virus lebih lanjut (Walker et al., 2020). Indonesia menerapkan strategi 
social distancing dan phycical distancing atau lebih dikenal dengan istilah Pembatasan Sosial Berskala Besar (PSBB) mulai bulan Maret 2020. Berdasarkan Peraturan Menteri Kesehatan Nomor 9 Tahun 2020 tentang Pedoman Pembatasan Sosial Berskala Besar dalam Rangka Percepatan Penanganan Corona Virus Disease 2019, PSBB dilakukan dengan menutup tempat kerja dan sekolah kecuali kantor atau instansi strategis seperti: Pertahanan dan keamanan; kebutuhan pangan; bahan bakar minyak dan gas; pelayanan kesehatan; industri; ekspor dan impor; dan distribusi logistik dan kebutuhan dasar lainnya.

Pada pelaksanaan PSBB pada bulan Maret hingga Mei 2020, banyak perusahaan atau kantor yang menerapkan Work From Home (WFH) sehingga memaksa perusahaan hanya membayar pegawai dengan sistem harian lepas. Hal tersebut berdampak pada penurunan tingkat pendapatan masyarakat khususnya masyarakat menengah ke bawah (Saputra \& Salma, 2020). Pasca pelaksanaan PSBB tepatnya pada bulan Juni 2020, terjadi booming sepeda di Indonesia. Masyarakat yang jenuh karena tidak dapat bekerja dan berlibur karena PSBB. Pesepedapesepeda baru ini menjadi fenomena dan bahkan menjadi sorotan dunia karena terdapat orang Indonesia yang sampai membeli seluruh stok sepeda lipat asal Inggris di sebuah toko sepeda daring di Jerman.

Strava adalah sebuah aplikasi layanan internet untuk melacak dan mencatat kegiatan olah raga (bersepeda dan berlari) dengan menggunakan data GPS dari telepon genggam maupun gawai lainnya. Strava sejak tahun 2009 telah mengumpulkan jutaan data dari para pesepeda dan pelari dari seluruh dunia. Strava Metro merupakan bagian kecil dari Strava yang memiliki fokus untuk membantu ahli tata kota dan Kementerian / Dinas Perhubungan untuk meningkatkan sarana dan prasarana bagi pesepeda dan pejalan kaki. Strava Metro menyediakan data tentang pola orang yang bergerak di suatu wilayah untuk memberikan keputusan yang berdampak dan berdasarkan data, baik merencanakan dan membangun infrastruktur baru atau mengukur dampak dan perubahan perilaku setelah proyek selesai. Penelitian ini bertujuan untuk melihat dampak PSBB akibat pandemi Covid-19 terhadap perilaku pesepeda pada masa sebelum dan setelah PSBB di Pulau Bali meliputi jumlah perjalanan, jumlah orang, demografi, dan tujuan perjalanan.

\section{METODE}

Penelitian dilaksanakan di Provinsi Bali dengan menggunakan data dari Strava Metro dengan periode data dari tahun 2017 sampai dengan bulan November 2020. Data Strava Metro bersifat anonim yang berarti tidak menampilkan identitas pesepeda kecuali jenis kelamin dan umur; dan menampilkan data dalam format sistem informasi geografis untuk mengetahui perilaku pesepeda di daerah tertentu. Data yang Strava berikan dalam bentuk database (dbf), Microsoft Excel dan format shape file (shp) (Strava Metro, 2020).

\section{HASIL DAN PEMBAHASAN}

Data Strava Metro dari tahun 2017 sampai dengan November 2020 di wilayah Provinsi Bali didapat berbagai macam data mulai dari demografis, asal pesepeda, jumlah total orang, dan total perjalanan. Jika dilihat dari Gambar 1 maka terjadi peningkatan jumlah pesepeda dari kategori umur 20-34 tahun yang pada tahun 2019 sebanyak 33,7\% dan 2020 sebanyak 49,3\%. Penurunan proporsi kategori umur 35-54 tahun terjadi di tahun 2020, sebanyak 54,8\% di tahun 2019 dan $38 \%$ di tahun 2020.

Penurunan asal pesepeda terjadi di tahun 2020, jika pada tahun 2019 persentase turis atau wisatawan yang bersepeda sebanyak $73,3 \%$ dibanding dengan orang lokal $26,7 \%$. Pada tahun 2020, persentase pesepeda lokal justru mengalami peningkatan dengan $73 \%$ dan turis atau wisatawan sebanyak 27\%. Hal ini disebabkan oleh pemberlakuan PSBB atau lockdown di 
seluruh wilayah Indonesia, yang membuat tempat-tempat wisata, pusat keramaian, dan hotel di Pulau Bali terpaksa menutup usahanya.

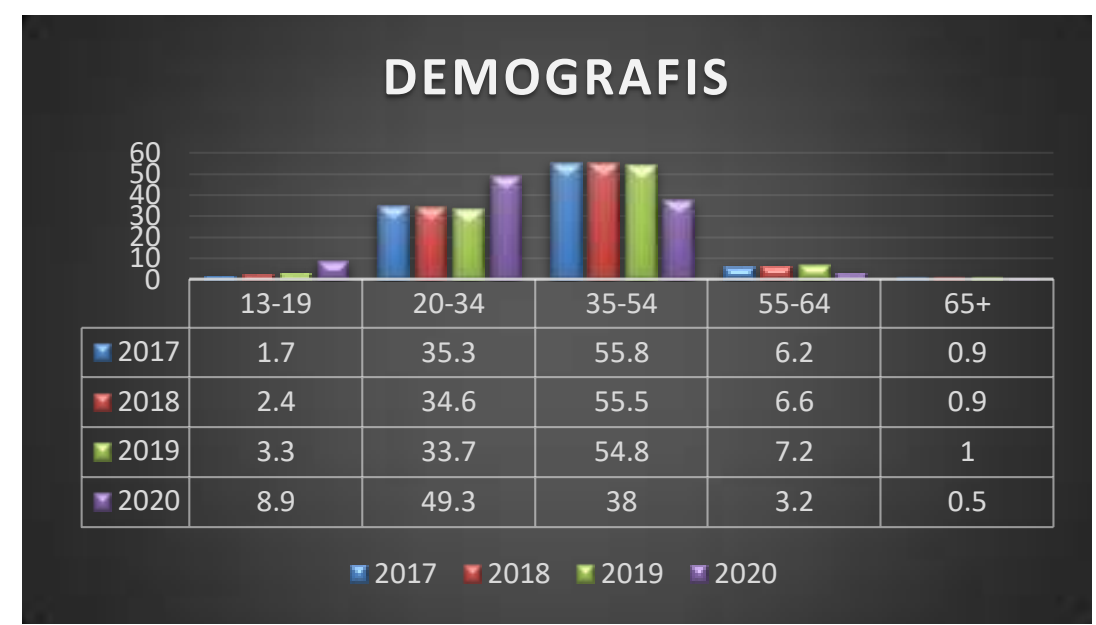

Gambar 1. Tabel dan Grafik Demografis Pesepeda di Provinsi Bali

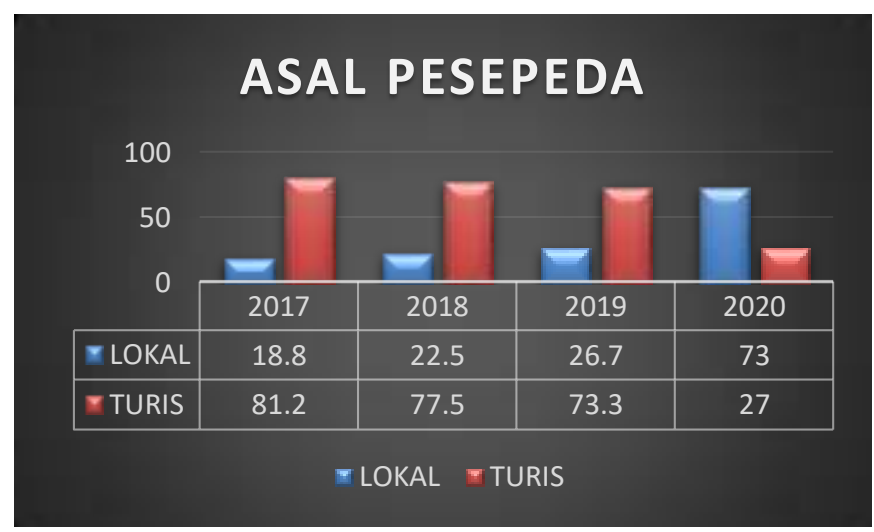

Gambar 2. Tabel dan Grafik Asal Pesepeda

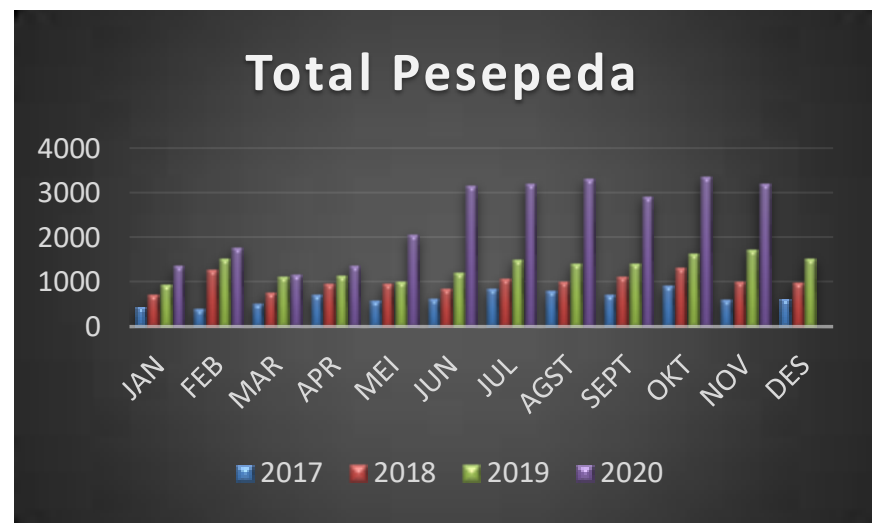

Gambar 3. Tabel dan Grafik Jumlah Total Pesepeda

Data Perjalanan Pesepeda

Strava mengumpulkan data mentah dari data GPS penggunanya seperti jalur yang dilewati, waktu tempuh bersepeda, dan tanggal bersepeda. Penelitian ini menggunakan data dari Strava Metro yang menampilkan jumlah perjalanan, jenis perjalanan (commute atau recreational), rentang umur, dan asal pesepeda (wisatawan atau lokal). 
Tabel 1.

Total Orang Bedasarkan Data Strava Metro 2017-2020

\begin{tabular}{|c|c|c|c|c|c|c|c|c|c|c|c|c|c|}
\hline \multirow{2}{*}{ TAHUN } & \multicolumn{12}{|c|}{ BULAN } & \multirow{2}{*}{ TOTAL } \\
\hline & Jan & Feb & Maret & Apr & Mei & Juni & Juli & Agusts & Sept & Okt & Nov & Des & \\
\hline 2017 & 444 & 400 & 513 & 709 & 589 & 631 & 855 & 801 & 714 & 923 & 619 & 624 & 7822 \\
\hline 2018 & 703 & 1272 & 773 & 962 & 969 & 868 & 1064 & 1020 & 1117 & 1320 & 1004 & 983 & 12055 \\
\hline 2019 & 940 & 1536 & 1113 & 1136 & 1021 & 1213 & 1505 & 1418 & 1417 & 1640 & 1722 & 1519 & 16180 \\
\hline 2020 & 1356 & 1782 & 1153 & 1379 & 2062 & 3177 & 3208 & 3322 & 2921 & 3352 & 3214 & & 26926 \\
\hline
\end{tabular}

Tabel 1 menunjukkan adanya peningkatan sebesar $101,95 \%$ pada bulan Mei 2020 dibandingkan dengan bulan Mei 2019. Puncaknya pada bulan Oktober 2020 yaitu 3.352 orang. Jumlah orang yang melakukan perjalanan dengan menggunakan sepeda baik untuk komuter maupun kegiatan wisata pada tahun 2020 mengalami peningkatan 66,4\% dari tahun 2019, data terakhir yang didapat sebanyak 3.214 orang pesepeda pada bulan November 2020.

Data Strava Metro dari tahun 2017 hingga November 2020 menunjukkan jumlah perjalanan menggunakan sepeda terdapat peningkatan dari tahun ke tahun. Berdasarkan data, pada tahun 2017 terdapat 22.197 perjalanan, tahun 2018 sebanyak 32.227 perjalanan (peningkatan 45,18\% dari tahun sebelumnya), tahun 2019 sebanyak 43.339 perjalanan (peningkatan 34,48\% dari tahun sebelumnya), dan pada tahun 2020 hingga bulan November sebanyak 123.542 (peningkatan 185,05\% dari tahun sebelumnya). Jika melihat data dari tahun 2020, pada bulan Mei hingga Juni 2020 terjadi lonjakan jumlah perjalanan sepeda hingga 35,63\%. Perjalanan bulan April 2020 sebanyak 6.435 perjalanan, bulan Mei sebanyak 9.889 perjalanan (peningkatan 34,92\% dari bulan sebelumnya) dan bulan Juni sebanyak 15.363 perjalanan (peningkatan 35,63\% dari bulan Mei) secara rinci dapat dilihat pada Tabel 2 di bawah ini:

Tabel 2.

Total Perjalanan Bedasarkan Data Strava Metro 2017-2020

\begin{tabular}{|c|c|c|c|c|c|c|c|c|c|c|c|c|c|}
\hline \multirow{2}{*}{ TAHUN } & \multicolumn{12}{|c|}{ BULAN } & \multirow{2}{*}{ TOTAL } \\
\hline & Jan & Feb & Maret & Apr & Mei & Juni & Juli & Agusts & Sept & Okt & Nov & Des & \\
\hline 2017 & 1503 & 1602 & 1946 & 2504 & 2103 & 2174 & 2644 & 2559 & 2469 & 2693 & 2018 & 2316 & 22197 \\
\hline 2018 & 2236 & 3662 & 2855 & 3275 & 3297 & 2791 & 3190 & 3088 & 3641 & 4192 & 3390 & 3302 & 32227 \\
\hline 2019 & 3246 & 4669 & 3927 & 3861 & 3694 & 4343 & 4675 & 4735 & 4655 & 5534 & 5898 & 5470 & 43339 \\
\hline 2020 & 5262 & 6015 & 4731 & 6435 & 9889 & 15363 & 15823 & 16001 & 13586 & 15234 & 15203 & & 123542 \\
\hline
\end{tabular}

\section{Total Trips}

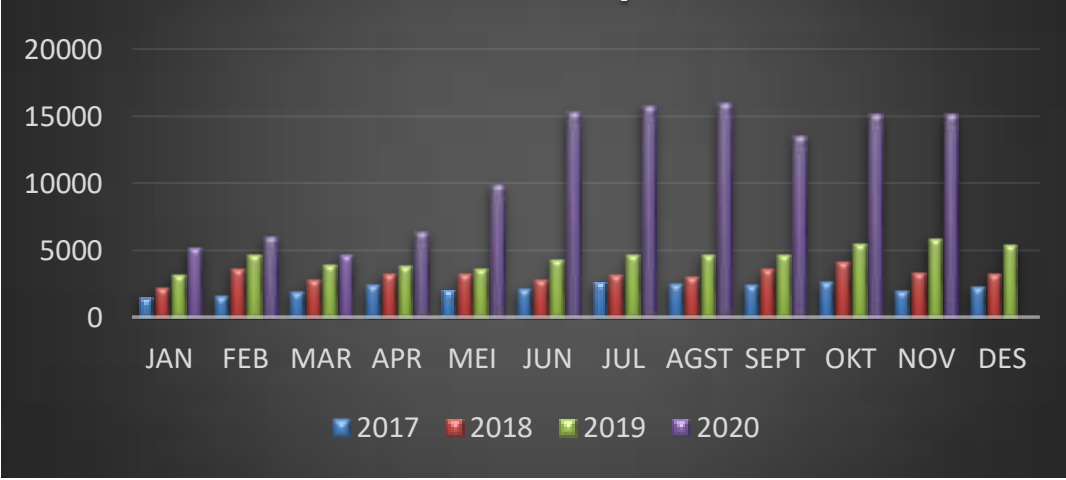

Gambar 4. Grafik Jumlah Perjalanan Sepeda di Pulau Bali 
Jika dilihat dari data di Gambar 2, maka didapat penurunan jumlah persentase wisatawan dibandingkan dengan pesepeda lokal. Pada tahun 2019 73,3\% pesepeda yang ada di Pulau Bali adalah wisatawan dibanding dengan pesepeda lokal sebesar 26,7\%. Sedangkan pada tahun 2020 pesepeda lokal mengalami peningkatan menjadi $73 \%$ dan wisatawan $27 \%$. Jumlah perjalanan sepeda mulai bulan Mei 2020 menunjukkan tren yang meningkat. Puncaknya pada bulan Agustus 2020 terdapat 16.001 perjalanan dan jumlah orang sebanyak 3.322 pesepeda. Jika dibandingkan dengan tahun 2019 pada bulan Agustus hanya mencatat jumlah pesepeda sebanyak 1.418 yang melakukan perjalanan sebanyak 4.735 perjalanan.

Dari data Strava Metro didapatkan peta perjalanan pesepeda berdasarkan jumlah trip yang ditampilkan dalam bentuk Heatmap. Jika ditelaah mayoritas pesepeda beraktivitas di Kota Denpasar dan sekitarnya karena memiliki jumlah penduduk lebih banyak dari daerah lain. Jalur wisata seperti ke arah Ubud, Kintamani, Bedugul, Kuta, Jimbaran dan Nusa Dua menjadi favorit para pesepeda. Peta persebaran pesepeda berdasarkan jumlah perjalanan di bulan Oktober 2020 dapat dilihat pada gambar di bawah ini:

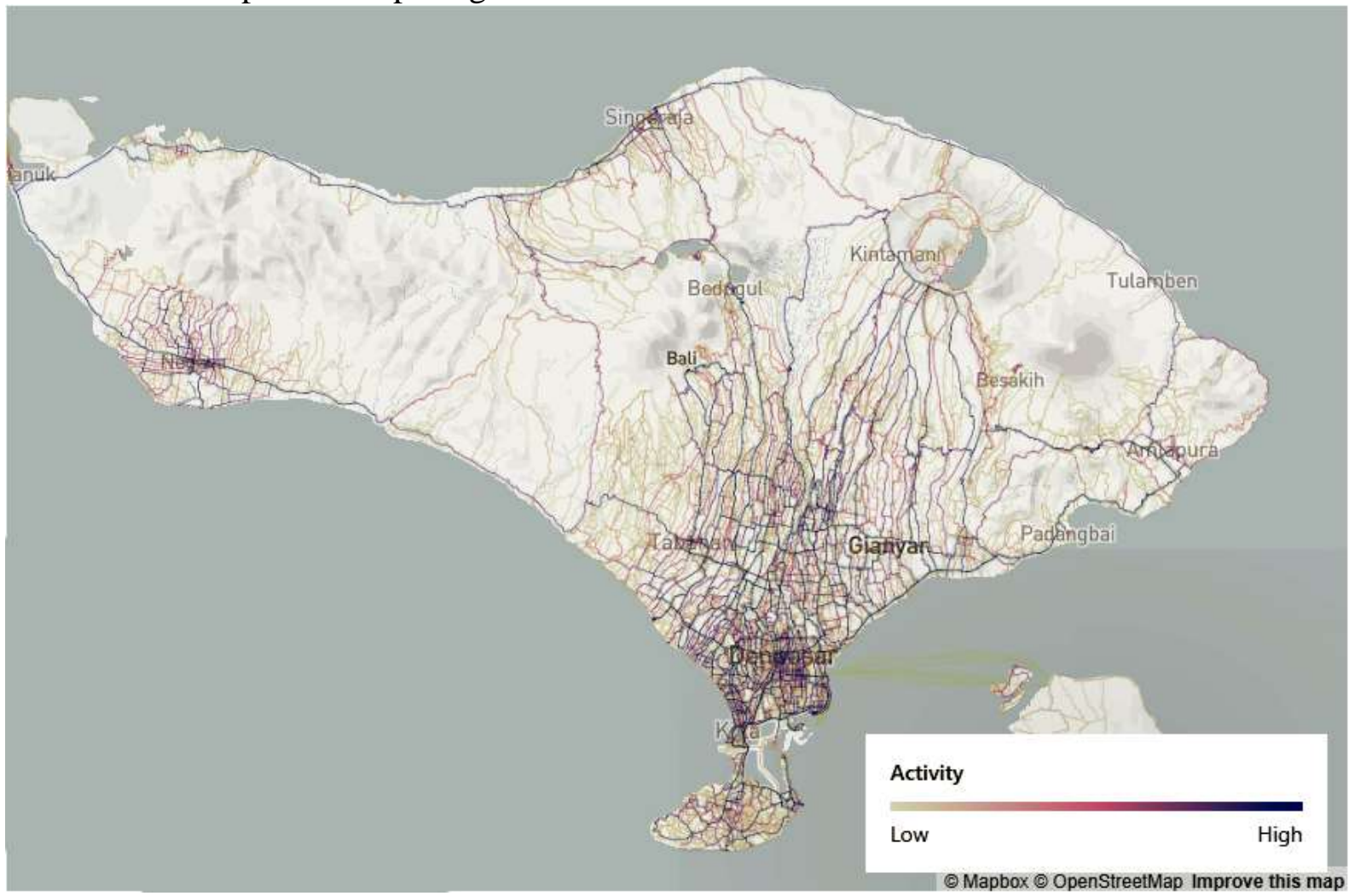

Gambar 5. Heatmap Jumlah Perjalanan Pesepeda di Pulau Bali menurut Data dari Pengguna Strava Bulan Oktober 2020

Tabel 3.

Total Commute Bedasarkan Data Strava Metro 2017-2020

\begin{tabular}{|c|c|c|c|c|c|c|c|c|c|c|c|c|c|}
\hline \multirow{2}{*}{ TAHUN } & \multicolumn{12}{|c|}{ BULAN } & \multirow{2}{*}{ TOTAL } \\
\hline & Jan & Feb & Maret & Apr & Mei & Juni & Juli & Agusts & Sept & Okt & Nov & Des & \\
\hline 2017 & 242 & 293 & 322 & 402 & 401 & 410 & 512 & 459 & 366 & 360 & 269 & 309 & 4345 \\
\hline 2018 & 302 & 426 & 401 & 541 & 475 & 391 & 544 & 447 & 497 & 482 & 398 & 376 & 5280 \\
\hline 2019 & 332 & 401 & 418 & 466 & 415 & 476 & 647 & 558 & 579 & 760 & 667 & 650 & 6369 \\
\hline 2020 & 613 & 648 & 449 & 410 & 638 & 1204 & 1255 & 1143 & 773 & 928 & 867 & & 8928 \\
\hline
\end{tabular}


Tabel 4.

Total Recreational Bedasarkan Data Strava Metro 2017-2020

\begin{tabular}{|c|c|c|c|c|c|c|c|c|c|c|c|c|c|}
\hline \multirow[b]{2}{*}{ TAHUN } & \multicolumn{12}{|c|}{ BULAN } & \multirow[b]{2}{*}{ TOTAL } \\
\hline & Jan & Feb & Maret & Apr & Mei & Juni & Juli & Agusts & Sept & Okt & Nov & Des & \\
\hline 2017 & 1261 & 1309 & 1624 & 2102 & 1702 & 1764 & 2132 & 2100 & 2103 & 2333 & 1749 & 2007 & 22186 \\
\hline 2018 & 1934 & 3236 & 2454 & 2734 & 2822 & 2400 & 2646 & 2641 & 3144 & 3710 & 2992 & 2926 & 33639 \\
\hline 2019 & 2914 & 4259 & 3509 & 3395 & 3279 & 3867 & 4028 & 4177 & 4076 & 4774 & 5231 & 4820 & 48329 \\
\hline 2020 & 4649 & 5367 & 4282 & 6025 & 9251 & 14159 & 14568 & 14858 & 12813 & 14312 & 14336 & & 114620 \\
\hline
\end{tabular}

\section{Jalur Sepeda di Kota Denpasar}

Pada tahun 2020 Pemerintah Kota Denpasar telah mengaktifkan kembali jalur sepeda sepanjang $25 \mathrm{~km}$ yang membentang dari Taman Lumintang Jalan Gatot Subroto hingga Pantai Sanur. Aktivasi jalur sepeda tersebut adalah jalur eksisting yang pada tahun 2010 telah dibangun oleh Pemerintah Kota Denpasar. Jalur sepeda tersebut untuk mengakomodir pesatnya peningkatan jumlah pesepeda khususnya di Kota Denpasar. Pembangunan jalur sepeda tersebut dibuat mendampingi jalur bus dalam kota (Trans Sarbagita dan Teman Bus) sehingga dapat menciptakan sistem transportasi terintegrasi antara halte bus dan pesepeda.

Perencanaan pembangunan rute jalur sepeda, pemilihan rute berkaitan dengan faktor-faktor seperti karakteristik perjalanan disamping tujuan dan pilihan atas moda. Pilihan dengan karakteristik perjalanan ditentukan oleh variasi atribut ruang, baik bentuk maupun fungsinya (Hannes et al, 2009). Rute bersepeda harus memperhatikan keberlanjutan rute yang direncanakan berdasarkan perilaku masyarakat dan kebutuhan perjalanan sebagai upaya integrasi sosial, ekonomi dan budaya. Partisipasi masyarakat dalam bersepeda saat ini dibatasi karena beberapa alasan. Jalur sepeda Kota Denpasar dapat dilihat pada gambar di bawah ini:

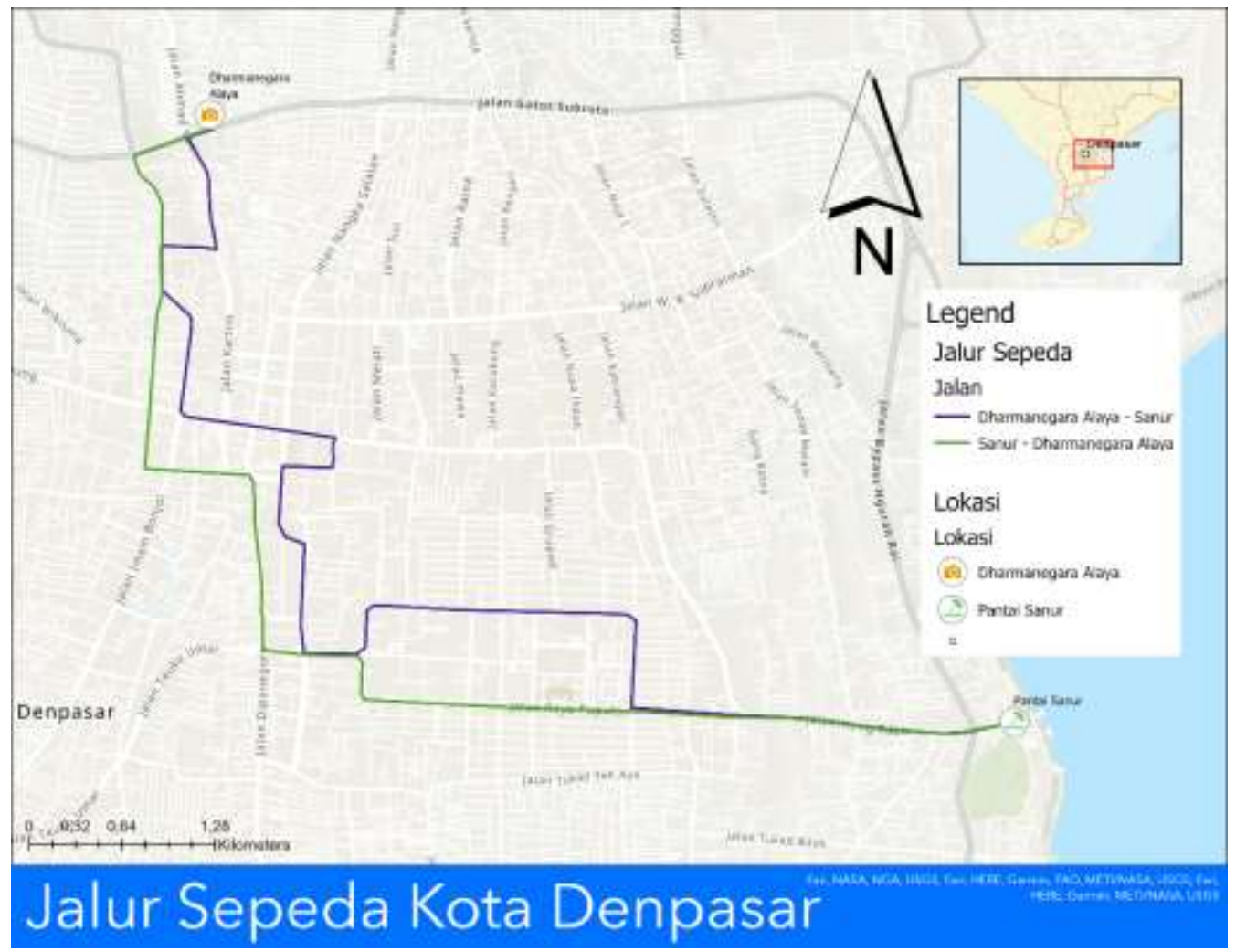

Gambar 6. Jalur Sepeda di Kota Denpasar 


\section{SIMPULAN}

Pandemi Covid-19 membawa tren baru di masyarakat, yaitu bersepeda. Bangkitnya hobi bersepeda disebabkan oleh masa karantina yang ditetapkan pemerintah membuat masyarakat tidak dapat berlibur ke tempat wisata. Pulau Bali sebagai pulau tujuan wisata yang menjadi fokus penelitian ini mengalami tren yang menarik. Diantaranya turunnya pesepeda dari luar Pulau Bali, pada tahun 2019 pesepeda lokal sebanyak 26,7\% dan wisatawan 73,3\%, sedangkan pada tahun 2020 pesepeda lokal sebanyak $73 \%$ dan wisatawan $27 \%$. Kenaikan pesepeda lokal juga diiringi dengan kenaikan jumlah perjalanan dan jumlah orang yang bersepeda di Pulau Bali. Jumlah pesepeda pada tahun 2019 sebanyak 16.180 orang, dibandingkan dengan tahun 2020 hingga bulan November sebanyak 26.926 orang. Jumlah total perjalanan juga mengalami peningkatan yaitu, pada tahun 2019 sebanyak 43.339 perjalanan dan tahun 2020 sebanyak 123.542 perjalanan. Peningkatan jumlah orang dan perjalanan pesepeda belum diiringi dengan dukungan pemerintah daerah. Jalur sepeda di Pulau Bali hanya terdapat di Kota Denpasar sepanjang 25 km.

\section{DAFTAR PUSTAKA}

Arifin, Z. M., Wicaksono, A., \& Permata, N. D. (2018). Kajian Stategi Penanganan Program Keselamatan Pesepeda. 19-20.

Hannes, Els, Davy Janssens and Geert Wets. (2009). Does Space Matter?Travel Mode Scripts in Daily Activity Travel. Environment and Behavior.Vol 41 Number 1, hal. 75-100. Sage Publications, http://eab.sagepub.com

Hasanuddin, U., Setiawan, R. S., Magister, M., Sipil, T., Islam, U., Agung, S., Rusmandani, P., Transportasi, P. K., Tegal, J., Mustafa, A. I., Keselamatan, P., \& Tegal, T. J. (2017). Analisis Perencanaan Penyediaan Lajur Khusus Sepeda Di Kota Tegal Dengan Metode Analytical Hierarchy Process ( Ahp ). November, 4-5.

Heesch, K. C., \& Langdon, M. (2016). The usefulness of GPS bicycle tracking data for evaluating the impact of infrastructure change on cycling behaviour. Health Promotion Journal of Australia, 27(3), 222-229. https://doi.org/10.1071/HE16032

Ilpaj, S. M., \& Nurwati, N. (2020). Analisis Pengaruh Tingkat Kematian Akibat Covid-19 Terhadap Kesehatan Mental Masyarakat Di Indonesia. Focus : Jurnal Pekerjaan Sosial, 3(1), 16. https://doi.org/10.24198/focus.v3i1.28123

Musakwa, W., \& Selala, K. M. (2016). Mapping cycling patterns and trends using Strava Metro data in the city of Johannesburg, South Africa. Data in Brief, 9, 898-905. https://doi.org/10.1016/j.dib.2016.11.002

Saputra, H., \& Salma, N. (2020). Dampak PSBB dan PSBB Transisi di DKI Jakarta dalam Pengendalian COVID-19. Media Kesehatan Masyarakat Indonesia, 16(3), 282-292. https://doi.org/10.30597/mkmi.v16i3.11042

Sri Sulasih, E. (2020). Ketidakefektifan Penerapan Pembatasan Sosial Berskala Besar (PSBB) di Daerah Khusus Ibukota Jakarta. Binamulia Hukum, 9(1), 67-82. https://doi.org/10.37893/jbh.v9i1.104

Strava Metro (2020). Better Data For Better Cities. https://metro.strava.com 
Sun, Y., Du, Y., Wang, Y., \& Zhuang, L. (2017). Examining associations of environmental characteristics with recreational cycling behaviour by street-level strava data. International Journal of Environmental Research and Public Health, 14(6). https://doi.org/10.3390/ijerph14060644

Walker, P. G., Whittaker, C., Watson, O., Baguelin, M., Ainslie, K. E. C., Bhatia, S., Bhatt, S., Boonyasiri, A., Boyd, O., Cattarino, L., Cucunubá, Z., Cuomo-Dannenburg, G., Dighe, A., Donnelly, C. A., Dorigatti, I., Van Elsland, S., Fitzjohn, R., Flaxman, S., Fu, H., ... Ghani, A. C. (2020). The Global Impact of COVID-19 and Strategies for Mitigation and Suppression. Imperial College COVID-19 Response Team, March(June), 19. https://doi.org/https://doi.org/10.25561/77735 